\title{
ROOT SYSTEM DISTRIBUTION OF SUGAR CANE AS RELATED TO NITROGEN FERTILIZATION, EVALUATED BY TWO METHODS: MONOLITH AND PROBES ${ }^{(1)}$
}

\author{
Rafael Otto $^{(2)}$, Paulo Cesar Ocheuze Trivelin ${ }^{(3)}$, Henrique Coutinho \\ Junqueira Franco $^{(4)}$, Carlos Eduardo Faroni ${ }^{(5)}$ \& André Cesar Vitti ${ }^{(6)}$
}

\begin{abstract}
SUMMARY
Few studies on sugar cane have evaluated the root system of the crop, in spite of its importance. This is mainly due to the difficulty of evaluation and high variability of results. The objective of this study was to develop an evaluation method of the cane root system by means of probes so as to evaluate the mass, distribution and metabolically active roots related to $\mathrm{N}$ fertilization at planting. For this purpose, an experiment was conducted in an Arenic Kandiustults with medium texture in Jaboticabal/SP, in a randomized block design with four replications and four treatments: control (without $N$ ) and 40,80 and $120 \mathrm{~kg} \mathrm{ha}^{-1}$ of $\mathrm{N}$ applied in the form of urea in the planting furrow of the cane variety SP81 3250. One week before harvest, a urea- ${ }^{15} \mathrm{~N}$ solution was applied at the cane stalk base to detect active metabolism in the root system. Trenches of $1.5 \mathrm{~m}$ length and $0.6 \mathrm{~m}$ depth were opened between two sugar cane rows for root sampling by two methods: monoliths (0.3, 0.2 and $0.15 \mathrm{~m}$ wide, deep and long respectively) taken from the trench wall and by probe (internal diameter $0.055 \mathrm{~m}$ ). For each method, 15 samples per plot were collected. The roots were separated from the soil in a sieve $(2 \mathrm{~mm}$ mesh), oven-dried (at $65^{\circ} \mathrm{C}$ ) and the dry matter was measured. Root sampling by probes resulted in root mass that did not differ from the evaluation in monoliths,
\end{abstract}

(1) Parte da Dissertação de Mestrado do primeiro autor. Programa de Pós Graduação em Solos e Nutrição de Plantas, Escola Superior de Agricultura Luiz de Queiroz - ESALQ/USP. Projeto financiado pela FAPESP. Recebido para publicação em dezembro de 2007 e aceito em março de 2009.

${ }^{(2)}$ Doutorando em Solos e Nutrição de Plantas, Escola Superior de Agricultura Luiz de Queiroz - ESALQ/USP. Caixa Postal 9, Av. Pádua Dias 11, CEP 13418-900 Piracicaba (SP). Bolsista FAPESP. E-mail: rotto@esalq.usp.br

${ }^{(3)}$ Professor Associado, Universidade de São Paulo - USP. Centro de Energia Nuclear na Agricultura - CENA. Laboratório de Isótopos Estáveis, Caixa Postal 96, CEP 13400-970 Piracicaba (SP). Bolsista CNPq. E-mail: pcotrive@cena.usp.br

(4) Pós-Doutorando, CENA-USP. Laboratório de Isótopos Estáveis, Caixa Postal 96, CEP 13400-970. Piracicaba (SP). Bolsista FAPESP. E-mail: hjfranco@cena.usp.br

(5) Pesquisador, Centro de Tecnologia Canavieira. Bairro Santo António, Caixa Postal 162, CEP 13400-970 Piracicaba (SP). Email: cfaroni@ctc.com.br

(6) Pesquisador Científico, Agência Paulista de Tecnologia dos Agronegócios, Pólo Regional Centro Sul. Rodovia SP 127, km 30, Vila Fátima, CEP 13400-970 Piracicaba (SP). E-mail: acvitti@apta.sp.gov.br 
indicating that this evaluation method may be used for sugar cane root mass, although neither the root distribution in the soil profile nor the rhizome mass were efficiently evaluated, due to the small sample volume. Nitrogen fertilization at planting did not result in a greater root accumulation in the sugar cane plant, but caused changes in the distribution of the root system in the soil. The absence of $\mathrm{N}$ fertilization led to a better root distribution in the soil profile, with 50, 34 and $16 \%$ in the 0-0.2, 0.2-0.4 and 0.4-0.6 m layers, respectively; in the fertilized treatments the roots were concentrated in the surface layer, with on average 70, 17 and $13 \%$ for the same layers. The metabolically active roots were concentrated in the center of the cane stool, amounting to $40 \%$ of the total root mass, regardless of $\mathrm{N}$ fertilization (application of $120 \mathrm{~kg} \mathrm{ha}^{-1} \mathrm{~N}$ or without $\mathrm{N}$ ).

Index terms: active roots, root sampling methods.

RESUMO: DISTRIBUIÇÃO DO SISTEMA RADICULAR DA CANA-DE-

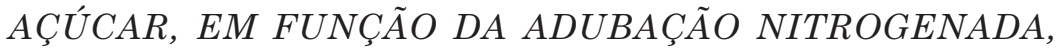
AVALIADOS POR DOIS MÉTODOS: MONÓLITO E SONDA

\begin{abstract}
Poucos estudos com cana-de-açúcar avaliaram o sistema radicular da cultura, apesar de sua importância. Esse fato é devido, em grande parte, à dificuldade de avaliação e à elevada variabilidade dos resultados. Objetivou-se com este trabalho avaliar um método de avaliação do sistema radicular da cana, por meio de sondagem, a fim de avaliar a massa, a distribuição e as raízes metabolicamente ativas em função da adubação nitrogenada de plantio. Para isso, foi conduzido experimento em um Latossolo Vermelho distrófico típico textura média, em Jaboticabal/SP, no esquema de blocos ao acaso com quatro repetições e quatro tratamentos:

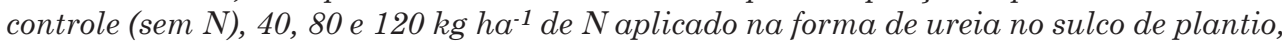
utilizando a cultivar SP81 3250. Uma semana antes da colheita, foi aplicada solução de ureia- ${ }^{15} \mathrm{~N}$ na base de colmos das plantas de cana-de-açúcar, para marcação do sistema radicular com metabolismo ativo. Foram abertas trincheiras de 1,5 $\mathrm{m}$ de largura e 0,6 $\mathrm{m}$ de profundidade entre duas linhas de cana, para permitir a amostragem de raízes por dois métodos: monólitos (0,3; 0,2 e 0,15 m de largura, profundidade e comprimento, respectivamente) retirados da parede da trincheira e sonda (0,055 $\mathrm{m}$ de diâmetro interno). Para cada método foram coletadas 15 amostras por parcela. As amostras de raizes foram separadas do solo por peneiramento (malha de $2 \mathrm{~mm}$ ) e secas em estufa, obtendo-se assim as massas de raizes secas. A amostragem de raízes com sonda resultou em massa de raízes que não diferiu da avaliação em monólito, indicando que esse método pode ser usado para avaliações da massa de raízes de cana-deaçúcar, porém não foi eficiente em avaliar tanto a distribuição das raízes no perfil do solo quanto a massa de rizomas, devido ao pequeno volume amostrado. A adubação nitrogenada de plantio não promoveu maior acúmulo de raízes na cana-planta, mas causou mudanças na distribuição do sistema radicular no solo. A ausência da adubação nitrogenada promoveu melhor distribuição do sistema radicular no perfil do solo, com 50, 34 e $16 \%$ nas camadas de o a 0,2, 0,2 a 0,4 e 0,4 a 0,6 $\mathrm{m}$ de profundidade, respectivamente; nos tratamentos fertilizados, em média, as raízes concentraram-se na camada superficial, com 70, 17 e 13 \% para as mesmas camadas. As raízes metabolicamente ativas concentraram-se no centro da touceira, totalizando $40 \%$ da massa total de raízes, independentemente da fertilização nitrogenada (sem $\mathrm{N}$ ou $120 \mathrm{~kg} \mathrm{ha}^{-1} \mathrm{~N}$ ).
\end{abstract}

Termos de indexação: raízes ativas, métodos de amostragem de raízes.

\section{INTRODUCTION}

For many years (until the middle of the last century), roots were considered the "hidden half" of plants (Waisel et al., 2002), with a significant scarcity of research results on this issue throughout the world. The reasons for this lack of data are historically explainable by methodological difficulties, by the inaccessibility of the root system itself as an object of experimentation, by its three-dimensional complexity and its notable spatial and temporal variability (van Noordwijk, 1993). In addition, the time required for activities of quantification of the root system and the uncertainties of the results were strongly discouraging factors for research on roots (Zonta et al., 2006). 
Currently, there is consensus on the importance of studying roots with direct field observations for crop management. When associated with soil-climate factors, research on roots is fundamental for optimizing fertilization practices, crop treatments, planting density, irrigation, intercalated crops, among other factors, as pointed out by Zonta et al. (2006). Furthermore, according to these authors, studies on roots are fundamental for understanding the relations of water and nutrient uptake by the crops.

One of the factors of greatest importance in the plant-water-soil relationship is the architecture and distribution of the plant root system, as well as the growth dynamic (Vasconcelos, 2002). Knowledge on the root system of sugar cane is prerequisite for an adequate use of agronomic techniques, such as: spacing, location of fertilizer application, cultural operations, soil drainage and irrigation systems, erosion control, use of intercalated crops, among others (Casagrande, 1991). However, the study of the root system is rather laborious. Additionally, the variability of the soil physical, chemical and biological conditions has an influence on root distribution and may lead to results that do not reflect reality. It is therefore important to define a time and labor-saving form of root sampling and with the highest possible accuracy and precision (Vasconcelos et al., 2003).

The principal evaluation methods of plant root systems are excavation, monoliths, auger, profile, tube or glass walls and indirect methods, in accordance with Böhm (1979), who describes each method in detail. The choice of the method of root system evaluation will depend on the crop, the edaphic conditions, if destructive sampling is possible or not, labor availability and, principally, the objectives of the study.

Of the measurable characteristics of the roots, the root length determines the potential for water and nutrient uptake from the soil; the root mass determines the total stock of underground material and accumulated nutrients; the root volume determines the soil volume occupied by the roots; the root area determines the water and nutrient uptake from the soil and the root diameter, in studies on microorganisms, regulation of hydric stress and roots as indicators of the influence of and response to chemical and physical soil conditions (Atkinson, 2000).

Köpke (1981) evaluated root distribution by the monolith, auger, profile and tube or "rhizotron" methods and stated the greatest root lengths by the monolith method, considered the standard method in studies on the root system. The author reported that root distribution may be estimated using all the methods as related to time, depth and, for example, the effects of cultivation however, they all only permit approximate determinations of the absolute root density. In the profile method, which consists of washing off of a layer of $5 \mathrm{~mm}$ in thickness from the walls of the soil profile and estimating the average length of exposed roots the relationship between the effort made and the information obtained was most favorable. Nevertheless, as this method underestimates root density compared with the standard method, the data had to be multiplied by a correction factor of 2.06 . According to the author, the auger method requires very little work, suggesting more studies with this method with a view to better evaluation.

Faroni (2004) verified that the probe method for root sampling, collecting six subsamples per location, was comparable with the monolith method in trenches for quantification of the total root system at most depths studied. Nevertheless, Vasconcelos et al. (2003) verified that the auger method, with two subsamples, overestimated the root quantity. This indicates that for techniques that evaluate a small soil volume, a greater number of subsamples is necessary to evaluate the root system distribution in the soil profile, to ensure more reliable results.

The development of an evaluation method of the sugar cane root system with relative operational ease in the field that provides reliable results is of interest to increase the number of studies with the root system of this crop in field experiments.

The development of the root system of perennial and semi-perennial crops, such as sugar cane, represents a complicating factor with regard to the root renewal between agricultural cycles (yearsharvests) in the same year, making the identification of live or metabolically active roots within the total sampled mass necessary (Faroni, 2004). The method of isotopic dilution with ${ }^{15} \mathrm{~N}$ allows the evaluation of the root mass with active metabolism and its distribution in the soil (Faroni \& Trivelin, 2006).

The objective of this study was to compare two methods of root system evaluation (probe and monolith), as well as the root system distribution and metabolically active roots of sugar cane in terms of $\mathrm{N}$ rates applied in the furrow at planting.

\section{MATERIAL AND METHODS}

The study was undertaken in a commercial sugar cane (Saccharum spp.) area at the Santa Adélia Sugar Cane Mill in Jaboticabal county, State of São Paulo (2119' 98 " S, 48 ${ }^{\circ} 19^{\prime} 03$ " W, $600 \mathrm{~m}$ alt).

The sugar cane variety SP81 3250 was planted in April 2005 and harvested in July 2006, completing an agricultural cycle of 15 months. Before planting, in January 2005, $2 \mathrm{t} \mathrm{ha}^{-1}$ of dolomitic lime was applied and $2 \mathrm{t} \mathrm{ha}^{-1}$ of agricultural gypsum, followed by one plowing and two diskings. Furrows were marked to a depth of $0.35 \mathrm{~m}$ at a spacing of $1.5 \mathrm{~m}$, together with the application of $120 \mathrm{~kg} \mathrm{ha}^{-1}$ of $\mathrm{P}_{2} \mathrm{O}_{5}$ and $120 \mathrm{~kg} \mathrm{ha}^{-1}$ 
of $\mathrm{K}_{2} \mathrm{O}$, from the sources triple superphosphate and potassium chloride respectively. Shoot stalk seed pieces with 15 viable buds per meter of row were used at planting and insecticide and nematicide were applied to the sugar cane seed pieces, followed by coverage of the seed pieces with a $0.1 \mathrm{~m}$ soil layer.

The experiment was arranged in a completely randomized block design with four treatments, corresponding to rates of 40,80 and $120 \mathrm{~kg} \mathrm{ha}^{-1}$ of N applied in the furrow in the form of urea, and one control (without $\mathrm{N}$ fertilization) with four replications. The plots consisted of 48 furrows with $15 \mathrm{~m}$ length spaced $1.5 \mathrm{~m}$ apart.

The soil of the experimental area is an Arenic Kandiustults (Soil Survey Staff, 2003) (Latossolo Vermelho distrófico típico, according to Embrapa, 2006). Undisturbed samples were collected to determine soil density and granulometry by the pipette method (Gee \& Or, 2002) and also for chemical analysis (Raij et al., 2001). The soil was chemically and physically analyzed at several depths by taking samples in an open trench in the border area of the experiments (Table 1).

In view of the need for evaluation of the sugar cane root system during the crop cycle, a non-destructive sampling method was used, using the SONDATERRA ${ }^{\circledR}$ probe (internal diameter $0.055 \mathrm{~m}$ ). However, the question arose - is the probe method comparable to the standard method of root sampling through monoliths taken from the trench walls? To answer this question, this study was carried out at the sugar cane harvest in July 2006 to evaluate the root mass by both the probe and the monolith methods.

Monolith method: Trenches between two rows of sugar cane, $1.5 \mathrm{~m}$ wide, $1.0 \mathrm{~m}$ long and $0.6 \mathrm{~m}$ deep, were opened. Soil monoliths (thickness $0.15 \mathrm{~m}$ ) with roots were removed from the walls of the trenches. Five monoliths of $0.3 \times 0.15 \times 0.2 \mathrm{~m}$ were removed per depth using a straight shovel and a model (square frame for the visualization of the monolith size) at depths of $0-0.2,0.2-0.4$ and $0.4-0.6 \mathrm{~m}$, totaling 15 monoliths with a volume of $9 \mathrm{dm}^{3}$ each, and a total of $135 \mathrm{dm}^{3}$ soil per trench.

After removal of the soil monoliths, the samples were placed in plastic bags. In the field, sieves $(2 \mathrm{~mm})$ were used to separate the soil from the roots and the rhizomes, which were placed in plastic bags. In the laboratory, roots and rhizomes were washed in tap water was carried out over sieves $(1 \mathrm{~mm})$. The root and rhizome samples were oven-dried at $65{ }^{\circ} \mathrm{C}$ for $72 \mathrm{~h}$ until constant weight was obtained on an analytical scale with precision of $0.01 \mathrm{~g}$. With the data of dry root and rhizome mass from each monolith $(\mathrm{g})$ and the volume at each sampling point in the trench $\left(9 \mathrm{dm}^{3}\right)$, the root density was obtained $\left(\mathrm{g} \mathrm{dm}^{-3}\right)$.

Probe method: Stainless steel probes (length $1.2 \mathrm{~m}$, internal diameter $0.055 \mathrm{~m}$ ) were used $\left(\right.$ SONDATERRA $\left.^{\circledR}\right)$. A probe sample corresponding to the position and depth of each monolith was taken, at a distance of around $0.10 \mathrm{~m}$ from the location from where the monoliths were taken (Figure 1). The volume of the soil and roots shown in each probe sample, with a depth of $0.2 \mathrm{~m}$, was $0.475 \mathrm{dm}^{3}$, totaling $7.13 \mathrm{dm}^{3}$ at the 15 points sampled in each trench. The soil and root volume sampled by the probe therefore represented $5.3 \%$ of the volume sampled by the monoliths.

The separation procedures of roots from the soil using the sieve and processing of the samples were the same as those cited for the monolith method. The mass of dry roots per hectare was calculated separately for each section of the soil profile, represented by one (1) monolith, as follows:

$$
\mathrm{RDM}=\mathrm{rd} \mathrm{x} \mathrm{sv}
$$

in which $\mathrm{RDM}=$ root dry mass, in $\mathrm{kg} \mathrm{ha}^{-1}$; $\mathrm{rd}=$ root density $\left(\mathrm{g} \mathrm{dm}^{-3}\right)$ for each one of the 15 points sampled, obtained by (2); sv = soil volume represented by each one of the 15 points sampled, in $\mathrm{m}^{3} \mathrm{ha}^{-1}$, obtained by (3).

$$
\mathrm{rd}=\mathrm{MR} / \mathrm{Vs}
$$

Table 1. Chemical and physical characterization of the Arenic Kandiustults (Latossolo Vermelho distrófico

\begin{tabular}{|c|c|c|c|c|c|c|c|c|c|c|c|c|}
\hline Diagnostic horizon & $\mathbf{p H}_{\mathrm{CaCl}_{2}}$ & S.O.M. & $\mathbf{P}$ & $\mathbf{K}^{+}$ & $\mathbf{C a}^{2+}$ & $\mathrm{Mg}^{2+}$ & $\mathrm{Al}^{3+}$ & $\mathbf{H}+\mathbf{A l}$ & $\mathbf{T}^{(1)}$ & $\mathbf{V}^{(1)}$ & Clay & $\rho^{(1)}$ \\
\hline & & $\mathrm{g} \mathrm{kg}^{-1}$ & $\mathrm{mg} \mathrm{kg}^{-1}$ & \multicolumn{6}{|c|}{$-\mathrm{mmol}_{\mathrm{c}} \mathrm{kg}^{-1}$} & $\%$ & $\mathrm{~g} \mathrm{~kg}^{-1}$ & $\mathrm{~kg} \mathrm{~m}^{-3}$ \\
\hline $\mathrm{Ap}(0.15 \mathrm{~m})$ & 5.6 & 23 & 10 & 3.6 & 18 & 13 & 0 & 17 & 51.6 & 67 & 285 & 1,305 \\
\hline $\mathrm{A}_{2}(0.37 \mathrm{~m})$ & 4.7 & 16 & 11 & 2.2 & 9 & 5 & 2 & 18 & 34.2 & 47 & 296 & 1,460 \\
\hline $\mathrm{AB}(0.56 \mathrm{~m})$ & 4.1 & 11 & 3 & 1.2 & 2 & 1 & 8 & 31 & 35.2 & 12 & 347 & 1,391 \\
\hline $\mathrm{BW}_{1}(0.96 \mathrm{~m})$ & 4.4 & 8 & 1 & 0.9 & 3 & 1 & 3 & 20 & 24.9 & 20 & 371 & 1,208 \\
\hline $\mathrm{BW}_{2}(0.96+)$ & 5.1 & 7 & 1 & 3.5 & 2 & 1 & 0 & 9 & 15.5 & 42 & 367 & 1,244 \\
\hline
\end{tabular}
típico)

(1) $\mathrm{T}=\mathrm{CEC}$ at $\mathrm{pH}: 7,0 ; \mathrm{V}=\left[\left(\mathrm{Ca}^{2+}+\mathrm{Mg}^{2+}+\mathrm{K}^{+}\right) / \mathrm{T}\right] \times 100$; chemical determinations according to Raij et al. (2001); $\rho$ : soil density. 


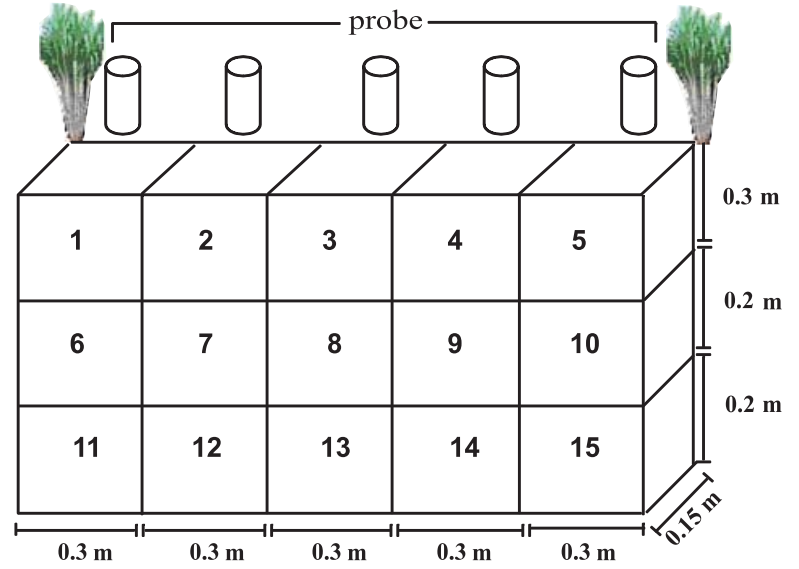

Figure 1. Sampling scheme of the root system by means of probes and monoliths taken from trench-profile walls.

in which MR = mass of dry roots obtained by the monolith or probe method, in each one of the 15 points sampled, in $\mathrm{g} ; \mathrm{Vs}_{\mathrm{s}}=$ volume sampled in each one of the 15 points, of $9 \mathrm{dm}^{3}$ for the monolith and 0.475 $\mathrm{dm}^{3}$ for the probe.

$$
\mathrm{sv}=\left[0.3 \mathrm{~m}_{\text {width }} \times 0.2 \mathrm{~m}_{\text {depth }} \times(10,000 / 1.5)\right]
$$

For the calculation of the dry root mass in the layer from 0 to $0.2 \mathrm{~m}, 0.2$ to 0.4 and 0.4 to $0.6 \mathrm{~m}$ the root mass of the five points that represented that layer were added. For the calculation of the total dry root mass, down to a depth of $0.6 \mathrm{~m}$, the mass of all 15 points sampled were summed up.

\section{Metabolically active roots}

The control treatments (without N) and $120 \mathrm{~kg} \mathrm{ha}^{-1}$ of urea-N, with four replications each, were selected for the study of metabolically active roots, according to the method described by Faroni (2004) and Faroni \& Trivelin (2006). The locations chosen for application of the urea solution enriched with ${ }^{15} \mathrm{~N}$ and for sampling of the root system were the same as of the trenches opened for the comparative study of the root sampling methods, as previously described. Each plot consisted of two segments of sugar cane rows of $1.5 \mathrm{~m}$ each, totaling three meters per plot.

The source used with the isotopic tracer ${ }^{15} \mathrm{~N}$ was urea at an abundance of $91.05 \%$ in ${ }^{15} \mathrm{~N}$ atoms, supplied at $40 \mathrm{~mL}$ solution at a concentration of $22.6 \%$ $(\mathrm{m} / \mathrm{v})$. This quantity was necessary to label the sugar cane plants with ${ }^{15} \mathrm{~N}$ (shoot and root system) so as to reach an enrichment of 0.7 atom $\%$ of ${ }^{15} \mathrm{~N}$, a sufficient content for the study. The sugar cane residue was removed from the marked plots and the number of stalks per plot counted. On July 5, 2006, a urea solution was applied through injection at the stalk base, using a $1 \mathrm{~mL}$ syringe and a needle with a thickness of $0.55 \mathrm{~mm}$ and length of $20 \mathrm{~mm}$. Care was taken so as not to let the solution return through the orifice needle opening at the base of the sugar cane stalk. This procedure was based on results of Faroni et al. (2007), who compared labeling methods of sugar cane biomass. Seven days after application of the ${ }^{15} \mathrm{~N}$ solution (sufficient time for $\mathrm{N}$ translocation through the plant, including the root system), the shoots and root system was sampled.

The samples collected by means of probes were placed in plastic bags and sealed to maintain humidity. In the laboratory, soil samples plus roots were weighed and a soil subsample was later taken to determine humidity. A subsample of the soil plus root residues was sieved through $2 \mathrm{~mm}$ mesh; what passed through the mesh was collected for later analysis of the total-N and ${ }^{15} \mathrm{~N}$ content. From each sampling location in the trenches, more "tender", lighcolored roots with a greater degree of branching were chosen, which were considered standards for metabolically active roots, according to Faroni (2004). The root samples, live root and soil with root residues were oven-dried at $65{ }^{\circ} \mathrm{C}$ for $72 \mathrm{~h}$ and then the dry matter was determined on an analytical balance (precision of $0.01 \mathrm{~g}$ ). The root samples (total and live) were passed through a Wiley type knife laboratory mill, taking care to avoid contamination among samples. The soil samples with root residues were passed through a ball mill for better homogenization. The soil subsamples of oven-dried at $105^{\circ} \mathrm{C}$ for $48 \mathrm{~h}$ to determine humidity. The $\mathrm{N}$ content and ${ }^{15} \mathrm{~N}$ abundance were also measured at CENA/USP using an automated mass spectrometer model ANCA-GSL of SERCON Co., UK (Barrie \& Prosser, 1996).

To calculate the mass of metabolically active roots of each sample, the isotopic abundance, masses and $\mathrm{N}$ content of the roots, live root and soil plus root residue samples were used, using the expression proposed by Faroni et al. (2007):

$$
\begin{gathered}
\mathrm{LRDMS}=\left\{\left[\left(\%{ }^{15} \mathrm{Nexc}_{\text {sample }}\right) /\left(\%{ }^{15} \mathrm{Nexc}_{\cdot \text { live root }}\right)\right] .\right. \\
\left.\mathrm{M}_{\text {sample }} \cdot \% \mathrm{~N}_{\text {sample }}\right\} / \% \mathrm{~N}_{\text {live root }}
\end{gathered}
$$

in which LRDMS = live root dry matter of sample, in mg; $\%{ }^{15} \mathrm{Nexc}_{\text {sample }}=$ percentage of ${ }^{15} \mathrm{~N}$ atoms in excess in the sample; $\%^{15}$ Nexc. live root $=$ percentage of ${ }^{15} \mathrm{~N}$ atoms in excess in the live root; $\% \mathrm{~N}_{\text {live root }}=\mathrm{N}$ content in the live root.

\section{Statistical analysis}

In the comparison of the mass of dry roots per hectare by the two methods and in terms of $\mathrm{N}$ rates, variance analyses were carried in a split plot design; plots represented the $\mathrm{N}$ rates and the subplots the evaluation methods. In the study of the root system distribution in terms of $\mathrm{N}$ fertilization at planting, variance analysis was carried out as a split plot design; plots represented the $\mathrm{N}$ rates and subplots the depths, separately for each evaluation method. When the value 
of the F Test was significant, the Tukey test was applied to verify possible differences between root distribution in the soil depths and the $\mathrm{N}$ rates.

\section{RESULTS AND DISCUSSION}

\section{Root mass in relation to the evaluation methods}

No significant difference was observed in the determination of dry root mass between the probe and the monolith method, regardless of the $\mathrm{N}$ rate (Table 2). Faroni (2004) observed a significant difference in root density at harvest between the monolith and probe methods, with values of 0.52 and $1.08 \mathrm{~g} \mathrm{dm}^{-3}$, respectively. According to the author, in the mean of four sampling periods, the methods were correlated for the depths of 0 to $0.2,0.2$ to 0.4 and 0.6 to $0.8 \mathrm{~m}$, although the probe overestimated root density.

Drew (1975) observed a significant increase in barley root branching caused by supplying $\mathrm{N}$ in a nutrient solution to specific parts of the root system, both for the ammonium and the nitrate source. A similar effect occurred for $\mathrm{P}$, while the $\mathrm{K}$ supply or lack of supply did not result in changes in the root structure. Sampaio et al. (1987) observed a significant effect in $\mathrm{N}$ fertilization at sugar cane planting on root mass at the time of harvest, where $1,700 \mathrm{~kg} \mathrm{ha}^{-1}$ of roots were measured of the control (without $\mathrm{N}$ ) and $2,250 \mathrm{~kg} \mathrm{ha}^{-1}$ at a rate of $60 \mathrm{~kg} \mathrm{ha}^{-1}$ of N.

The root density observed in this study was slightly below the data found in the literature. At sugar cane harvest, in the average $\mathrm{N}$ rates and evaluation methods, the density was $0.38 \mathrm{~g} \mathrm{dm}^{-3}$ or $2,270 \mathrm{~kg} \mathrm{ha}^{-1}$, considering live and dead roots and without

Table 2. Dry root mass of sugar cane down to a depth of $0.6 \mathrm{~m}$ at harvest (July/2006) as related to nitrogen fertilization at planting, by two evaluation methods

\begin{tabular}{|c|c|c|}
\hline \multirow{2}{*}{$\mathrm{N}$ rate } & \multicolumn{2}{|c|}{ Method } \\
\hline & Probe & Monolith \\
\hline $\mathrm{kg} \mathrm{ha}^{-1}$ & \multicolumn{2}{|c|}{$\mathrm{kg} \mathrm{ha}^{-1}\left(\mathrm{~g} \mathrm{dm}^{-3}\right)$} \\
\hline 0 & $2,313(0.39)$ a $\mathrm{A}$ & $2,478(0.41)$ a $\mathrm{A}$ \\
\hline 40 & $2,266(0.38)$ a A & $2,857(0.48)$ a $\mathrm{A}$ \\
\hline 80 & $2,253(0.38)$ a A & $2,017(0.34)$ a $\mathrm{A}$ \\
\hline 120 & $1,920(0.32)$ a $\mathrm{A}$ & $2,168(0.36)$ a $\mathrm{A}$ \\
\hline Mean & $2,188(0.36) \mathrm{A}$ & $2,347(0.40) \mathrm{A}$ \\
\hline $\mathrm{VC}^{(1)}$ & 32.8 & 37.3 \\
\hline
\end{tabular}

(1) VC: variation coefficient. Means followed by the same lowercase letters in the columns and equal capital letters in the lines are not significantly different by the Tukey test at $5 \%$. considering rhizomes to a depth of $0.6 \mathrm{~m}$. Ball-Coelho et al. (1992) observed root density at sugar cane harvest of $0.75 \mathrm{~g} \mathrm{dm}^{-3}$ and in the ratoon of 0.9 to $1.10 \mathrm{~g} \mathrm{dm}^{-3}$ in a clay soil in the Northeast of Brazil, down to a depth of $2.0 \mathrm{~m}$. Vasconcelos et al (2003), down to a depth of $0.8 \mathrm{~m}$, found a root density varying from 0.63 to $0.76 \mathrm{~g} \mathrm{dm}^{-3}$ in the ratoon of the fifth cutting, in soil with a similar texture as that of this study, although alic. Faroni (2004) detected a root density of $0.52 \mathrm{~g} \mathrm{dm}^{-3}$ by the monolith method in an Oxisol with sandy texture down to a depth of $0.8 \mathrm{~m}$, at the harvest of the third cutting of the variety RB85 5156 , In the case of ratoons, the higher root densities found in these studies were probably due to the accumulation of total root mass according to the succession of sugar cane cuttings, apart from other factors related to root development.

It should be emphasized that only root mass was compared in this study, without considering rhizome data, similar to the study undertaken by Vasconcelos et al. (2003). The probe method did not permit estimation of the rhizomes mass of sugar cane, which impeded comparisons with the monolith method for this plant part.

Sampaio et al. (1987) observed greater mass of underground stalks $\left(3.6 \mathrm{t} \mathrm{ha}^{-1}\right)$ than that of roots $\left(1.7 \mathrm{tha}^{-1}\right.$ in the control and $2.25 \mathrm{t} \mathrm{ha}^{-1}$ at a rate of $60 \mathrm{~kg} \mathrm{ha}^{-1}$ of N) at harvest, while Faroni (2004) found, in the mean of four evaluation periods in $1^{\text {st }}$ ratoon cane, $3.8 \mathrm{t} \mathrm{ha}^{-1}$ of roots and $1.8 \mathrm{t} \mathrm{ha}^{-1}$ of rhizomes, highlighting the importance of quantification of this part of the root system in sugar cane studies because it is a nutrient reserve for the crop.

The probe method for evaluation of the sugar cane root system can therefore be used in studies of the total root mass in the soil profile, with advantages in terms of ease and speed of evaluations, compared to the monolith method. Through the fact of permitting a more rapid root sampling in each plot, the probe method allows more treatments or replications to be collected than the monolith method, which takes at least twice as much time for the sampling of each plot, as observed in this study. Nevertheless, if rhizome quantification is necessary, preference must be given to the methods which examine a greater soil volume, such as open trenches in row projection (for example, collecting the entire rhizome mass at 1 or $2 \mathrm{~m}$ in the sugar cane row). The probe method did not permit estimation of the rhizome mass in the sugar cane crop due to the small volume sampled with this equipment.

\section{Root system distribution related to the evaluation methods}

By the monolith method, in the mean of the treatments, 65,22 and $13 \%$ of the roots are found in the soil layers $0-0.2,0.2-0.4$ and $0.4-0.6 \mathrm{~m}$, respectively (Table 3 ). By the probe method, the distribution was 52,28 and $20 \%$ at the same levels. 
While the monolith method evidenced greater root mass in the layer $0-0.2 \mathrm{~m}$ for the $\mathrm{N}$ rate of $40 \mathrm{~kg} \mathrm{ha}^{-1}$, compared with the control (without $\mathrm{N}$ ) and the rate of $120 \mathrm{~kg} \mathrm{ha}^{-1}$, no significant difference was found by the probe method in the mass of root dry matter with the $\mathrm{N}$ rate in any soil layer studied. This fact may be due to the lower soil volume sampled with the probe, which did not permit identification of small differences in the root mass among treatment, unlike the monolith method.

For more detailed studies however, which require a higher degree of accuracy, on the root system distribution in the soil for example, the probe method with the diameter used in this study may not be adequate, since it may result in erroneous conclusions. In these cases the monolith method the standard sampling method of the root system, is recommended (Kopke, 1981).

\section{Root system distribution related to nitrogen fertilization}

The root density decreased exponentially with soil depth and increasing distance from the crop rows, regardless of $\mathrm{N}$ fertilization at planting (Table 4). Highest root densities were found in the layers nearest to the soil surface and near the center of the cane stool, indicating concentrated growth of the root system

Table 3. Distribution of the sugar cane root system in the soil profile, in terms of depth and nitrogen fertilization at planting by two evaluation methods

\begin{tabular}{|c|c|c|c|c|c|c|c|c|c|c|}
\hline \multirow{3}{*}{$\begin{array}{c}\text { Depth } \\
\mathrm{m}\end{array}$} & \multicolumn{8}{|c|}{$\mathrm{N}$ rate $\left(\mathrm{kg} \mathrm{ha}^{-1}\right)$} & \multirow{2}{*}{\multicolumn{2}{|c|}{ Mean }} \\
\hline & \multicolumn{2}{|l|}{0} & \multicolumn{2}{|l|}{40} & \multicolumn{2}{|l|}{80} & \multicolumn{2}{|l|}{120} & & \\
\hline & $\mathrm{kg} \mathrm{ha-1}$ & $\%$ & $\mathrm{~kg} \mathrm{ha-1}$ & $\%$ & $\mathrm{~kg} \mathrm{ha-1}$ & $\%$ & $\mathrm{~kg} \mathrm{ha-1}$ & $\%$ & $\mathrm{~kg} \mathrm{ha-1}$ & $\%$ \\
\hline \multicolumn{11}{|c|}{ Monolith } \\
\hline $0-0.2$ & $1,247 \mathrm{aB}$ & $(50)$ & 2,230 a $\mathrm{A}$ & (78) & $1,414 \mathrm{a} \mathrm{AB}$ & $(70)$ & 1,291 a B & $(60)$ & $1,545 \mathrm{a}$ & (65) \\
\hline $0.2-0.4$ & $847 \mathrm{abA}$ & (34) & $346 \mathrm{~b} \mathrm{~A}$ & (12) & $328 \mathrm{~b} \mathrm{~A}$ & (16) & $531 \mathrm{abA}$ & (24) & $513 \mathrm{~b}$ & (22) \\
\hline $0.4-0.6$ & $384 \mathrm{~b} \mathrm{~A}$ & (15) & $281 \mathrm{~b} \mathrm{~A}$ & (10) & $275 \mathrm{~b} \mathrm{~A}$ & (14) & $346 \mathrm{~b} \mathrm{~A}$ & (16) & $322 \mathrm{~b}$ & (13) \\
\hline Total & $2,478 \mathrm{~A}$ & & $2,857 \mathrm{~A}$ & & $2,017 \mathrm{~A}$ & & $2,168 \mathrm{~A}$ & & & \\
\hline \multicolumn{11}{|c|}{ Probe } \\
\hline $0-0.2$ & $1,136 \mathrm{aA}$ & (49) & $1,193 \mathrm{aA}$ & (53) & $1,237 \mathrm{a} \mathrm{A}$ & $(55)$ & 1,005 a A & $(52)$ & $1,143 \mathrm{a}$ & (52) \\
\hline $0.2-0.4$ & $697 \mathrm{abA}$ & (30) & $671 \mathrm{abA}$ & (30) & $580 \mathrm{~b} \mathrm{~A}$ & (26) & $517 \mathrm{abA}$ & (27) & $616 \mathrm{~b}$ & (28) \\
\hline $0.4-0.6$ & $481 \mathrm{bA}$ & (21) & $401 \mathrm{~b} \mathrm{~A}$ & (18) & $438 \mathrm{~b} \mathrm{~A}$ & (19) & $399 \mathrm{bA}$ & (21) & $439 \mathrm{~b}$ & (20) \\
\hline Total & $2,313 \mathrm{~A}$ & & $2,266 \mathrm{~A}$ & & $2,255 \mathrm{~A}$ & & $1,920 \mathrm{~A}$ & & & \\
\hline
\end{tabular}

Means followed by the same lower-case letters among depths and equal capital letters among nitrogen rates are not significantly different by the Tukey test at $5 \%$. Numbers in brackets represent the root percentage at each depth.

Table 4. Root density in terms of depth and distance from the sugar cane stool with or without N fertilization

\begin{tabular}{|c|c|c|c|c|c|c|}
\hline \multirow{2}{*}{ Depth } & \multicolumn{5}{|c|}{ Distance from the cane row (m) } & \multirow{2}{*}{ Average } \\
\hline & $0-0.3$ & $0.3-0.6$ & $0.6-0.9$ & $0.3-0.6$ & $0-0.3$ & \\
\hline \multirow[t]{2}{*}{$\mathrm{m}$} & & 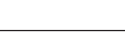 & - & & & - \\
\hline & \multicolumn{6}{|c|}{ Without $\mathrm{N}$ fertilization } \\
\hline $0-0.2$ & 1.71 & 0.33 & 0.18 & 0.22 & 0.68 & 0.62 \\
\hline $0.2-0.4$ & 0.84 & 0.12 & 0.06 & 0.07 & 1.02 & 0.42 \\
\hline $0.4-0.6$ & 0.23 & 0.09 & 0.06 & 0.09 & 0.48 & 0.19 \\
\hline \multirow[t]{2}{*}{ Average } & 0.93 & 0.18 & 0.10 & 0.13 & 0.73 & 0.41 \\
\hline & \multicolumn{6}{|c|}{ With $\mathrm{N}$ fertilization ${ }^{(1)}$} \\
\hline $0-0.2$ & 1.83 & 0.21 & 0.22 & 0.22 & 1.63 & 0.82 \\
\hline $0.2-0.4$ & 0.41 & 0.08 & 0.06 & 0.08 & 0.38 & 0.20 \\
\hline $0.4-0.6$ & 0.23 & 0.07 & 0.07 & 0.06 & 0.32 & 0.15 \\
\hline Average & 0.82 & 0.12 & 0.12 & 0.12 & 0.78 & 0.39 \\
\hline
\end{tabular}

${ }^{(1)}$ Average of the results obtained applying three $\mathrm{N}$ rates $\left(40,80\right.$ and $\left.120 \mathrm{~kg} \mathrm{ha}^{-1}\right)$ 
at this location. The average general root density was similar in the treatments, with $0.41 \mathrm{~g} \mathrm{dm}^{-3}$ in the control and $0.39 \mathrm{~g} \mathrm{dm}^{-3}$ in the $\mathrm{N}$-fertilized treatments, in the mean of the three nitrogen rates (Table 4).

In relation to the vertical root distribution in the soil, in the treatment without $\mathrm{N}$ fertilization, the average root density was $0.62 \mathrm{~g} \mathrm{dm}^{-3}$ in the $0-0.2 \mathrm{~m}$ layer, $0.42 \mathrm{~g} \mathrm{dm}^{-3}$ in $0.2-0.4 \mathrm{~m}^{2}$ and $0.19 \mathrm{~g} \mathrm{dm}^{-3}$ in $0.4-$ $0.6 \mathrm{~m}$; in the $\mathrm{N}$-fertilized treatments, the density was $0.82,0.20$ and $0.15 \mathrm{~g} \mathrm{dm}^{-3}$ for these layers, indicating higher density in the surface and lower density in the deeper layers, compared to the control (Table 4).

Nitrogen fertilization at planting caused changes in the distribution of the total sugar cane root mass (Table 5). In general speaking, $\mathrm{N}$ fertilizer led to intensified root growth in the surface layer and reduced root growth in the deeper layers. On average, in the control treatment (without $\mathrm{N}$ fertilization), $50 \%$ of the roots were found in the 0-0.2 $\mathrm{m}$ layer, $34 \%$ in $0.2-0.4$ and $15 \%$ in $0.4-0.6 \mathrm{~m}$. With $\mathrm{N}$ fertilization, on average, around $70 \%$ of the roots were concentrated in the $0-0.2 \mathrm{~m}$ layer, $17 \%$ in $0.2-0.4 \mathrm{~m}$ and $13 \%$ in 0.4-0.6 m. Results of Sampaio et al. (1987) indicated greater root mass at a depth of $0.2 \mathrm{~m} \mathrm{3,6}$ and 16 months after planting in the treatment fertilized with $60 \mathrm{~kg} \mathrm{ha}{ }^{-1}$ of $\mathrm{N}$ in relation to the control, corroborating the results obtained here. In that study, $\mathrm{N}$ fertilization also favored root concentration at a depth of $0.3 \mathrm{~m}$ on either side of the planting furrow 3, 6 and 11 months after planting in relation to the control, which was however not verified in this study (Table 5).

The absence of $\mathrm{N}$ fertilization favored, therefore, better distribution of the root system in the soil profile. One hypothesis for explaining this fact is that in the case of unfertilized plots, the root system had to use a greater soil volume for the uptake of nutrients, including $\mathrm{N}$, since this nutrient might not be available in a sufficient quantity in the zone of root uptake. On the other hand, the roots of $\mathrm{N}$-fertilized plants developed more intensely near the $\mathrm{N}$-fertilized soil region, favoring root concentration in the soil surface, which was observed by Drew (1975) and Sampaio et al. (1987) as well. Greater root concentration in the surface layer, favored by $\mathrm{N}$ fertilizer, may be harmful for a sugar cane plantation under water deficit.

Studies regarding the root distribution in the soil profile may be useful for a series of reasons, such as the recommendation for fertilizer location for ratoon fertilization, control of pests that attack the root system, regulation of the machine traffic in cane harvest operations, among others. Using a equation (1), the dry root mass for each location in the soil profile ( $\mathrm{kg} \mathrm{ha}^{-1}$ ) was obtained, using the average root densities found in all treatments. In relation to the root system distribution in the vertical soil profile, $65 \%$ of the total root mass was found in the first $0.2 \mathrm{~m}$. In the horizontal direction, $81 \%$ of the total root mass was found in the $0.6 \mathrm{~m}$ near the sugar cane stool (0.3 $\mathrm{m}$ from each crop row), down to a depth of $0.6 \mathrm{~m}$ (Figure 2).

A small root quantity was observed between the crop rows, especially at greater depths. Factors directly related to the root development are aeration, water, temperature and mechanical resistance to root penetration (Letey, 1985). In addition, chemical factors such as adequate availability of $\mathrm{Ca}, \mathrm{P}$ and absence of $\mathrm{Al}$ also influenced plant root growth.

The heterogeneity of root system distribution in the soil profile may be associated with a series of factors. Soil compaction is a very important one for the sugar

Table 5. Dry root mass in terms of depth and distance from the sugar cane stool in treatments with or without $\mathrm{N}$ fertilization

\begin{tabular}{|c|c|c|c|c|c|c|}
\hline \multirow{2}{*}{ Depth } & \multicolumn{5}{|c|}{ Distance from the cane row (m) } & \multirow{2}{*}{ Total } \\
\hline & $0-0.3$ & $0.3-0.6$ & $0.6-0.9$ & $0.3-0.6$ & $0-0.3$ & \\
\hline \multirow[t]{2}{*}{$\mathrm{m}$} & & & 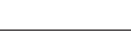 & 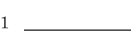 & 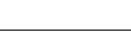 & - \\
\hline & \multicolumn{6}{|c|}{ Without $\mathrm{N}$ fertilization } \\
\hline $0-0.2$ & $682(28)$ & $132(5)$ & $73(3)$ & $88(4)$ & $271(11)$ & $1,247(50)$ \\
\hline $0.2-0.4$ & $338(14)$ & $46(2)$ & $24(1)$ & $30(1)$ & $410(17)$ & $847(34)$ \\
\hline $0.4-0.6$ & $92(4)$ & $37(2)$ & $23(1)$ & $38(2)$ & $193(8)$ & $384(16)$ \\
\hline \multirow[t]{2}{*}{ Total } & $1,113(45)$ & $215(9)$ & $120(5)$ & $156(6)$ & $874(35)$ & $2,477(100)$ \\
\hline & \multicolumn{6}{|c|}{ With $\mathrm{N}$ fertilization ${ }^{(1)}$} \\
\hline $0-0.2$ & $731(31)$ & $85(4)$ & $86(4)$ & $90(4)$ & $653(28)$ & $1,645(70)$ \\
\hline $0.2-0.4$ & $164(7)$ & $31(1)$ & $24(1)$ & $32(1)$ & $150(6)$ & 402 (17) \\
\hline $0.4-0.6$ & $92(4)$ & 29 (1) & $28(1)$ & $24(1)$ & $128(5)$ & 301 (13) \\
\hline Total & $987(42)$ & $145(6)$ & $139(6)$ & $146(6)$ & $931(40)$ & $2,347(100)$ \\
\hline
\end{tabular}

(1) Mean of the results obtained applying three $\mathrm{N}$ rates $\left(40,80\right.$ and $\left.120 \mathrm{~kg} \mathrm{ha}^{-1}\right)$. Values in brackets represent the percentage of roots at each location. 


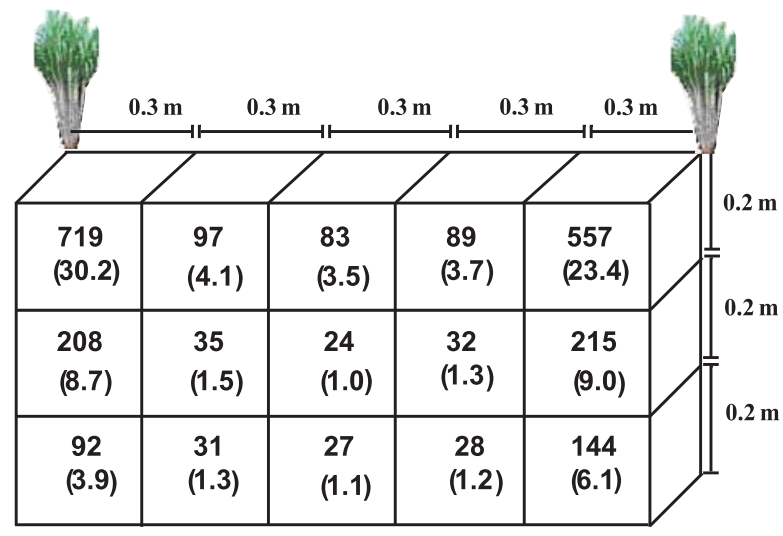

Figure 2. Average distribution of the sugar cane dry root mass in the soil profile evaluated by the monolith method. Average of four treatments (without $\mathrm{N} ; 40,80$ and $120 \mathrm{~kg} \mathrm{ha}^{-1}$ of urea-N). Numbers in brackets represent the root percentage at each location.

cane crop due to intense machine traffic between crop rows, leading to an increase in soil density and consequent reduction of porosity and $\mathrm{O}_{2}$ diffusion.

At the time of opening the trenches, a more compacted layer between 0.2 and $0.3 \mathrm{~m}$ in depth was diagnosed, causing difficulty in opening the trenches by the work team. The soil density, obtained by means of undisturbed soil samples collected from the trench walls (where the monoliths were taken from), was $1,530 \mathrm{~kg} \mathrm{~m}^{-3}$ along the row and $1,570 \mathrm{~kg} \mathrm{~m}^{-3}$ between the crop rows, $0.75 \mathrm{~m}$ away from the row (Table 6).

The greatest differences were found in relation to depths, with slightly greater compaction in the layer $0.2-0.4 \mathrm{~m}$, with an average density of $1,620 \mathrm{~kg} \mathrm{~m}^{-3}$, higher than in the layer $0-0.2 \mathrm{~m}\left(1,490 \mathrm{~kg} \mathrm{~m}^{-3}\right)$ and in $0.4-0.6 \mathrm{~m}\left(1,530 \mathrm{~kg} \mathrm{~m}^{-3}\right)$. This compaction in the layer $0.2-0.4 \mathrm{~m}$ may be the main reason why $65 \%$ of the roots were found above this layer. Nevertheless, no morphological signs of root compaction, such as root flattening (Trouse Jr., 1967), were observed in any of the layers evaluated.

Table 6. Soil density in the trenches at sugar cane harvest, at different locations and depths. Results correspond to the mean of 16 replications

\begin{tabular}{cccc}
\hline Depth & Crop row & Between crop row & Mean \\
\hline $\mathrm{m}$ & & $\mathrm{kg} \mathrm{m}^{-3}$ & \\
\cline { 3 - 3 } $0-0.2$ & 1,460 & 1,530 & 1,490 \\
$0.2-0.4$ & 1,610 & 1,640 & 1,620 \\
$0.4-0.6$ & 1,510 & 1,540 & 1,530 \\
Average & 1,530 & 1,570 & \\
\hline
\end{tabular}

In addition to compaction, the $\mathrm{AB}$ horizon ( 0.38 to $0.56 \mathrm{~m})$ had low contents of $\mathrm{P}\left(3 \mathrm{mg} \mathrm{dm}^{-3} \mathrm{P}\right), \mathrm{Ca}$ $\left(2 \mathrm{mmol}_{\mathrm{c}} \mathrm{m}^{-3} \mathrm{Ca}\right)$, and $\mathrm{Mg}\left(1 \mathrm{mmol}_{\mathrm{c}} \mathrm{m}^{-3} \mathrm{Mg}\right)$ and low soil base saturation (16\%) and high Al content $\left(8 \mathrm{mmol}_{\mathrm{c}} \mathrm{m}^{-3}\right)$ and $\mathrm{Al}$ saturation (65\%), which may have limited deep root development. According to Furlani (1983), the high Al content in in the soil is not only toxic to plants and reduces root growth, but also causes $P$ fixation in less available forms, reducing the soil respiration rate and interfering with enzymatic reactions responsible for the deposit of polysaccharides on cell walls, as well as modifying the uptake and transport dynamic of different nutrients, mainly of $\mathrm{Ca}$ and $\mathrm{Mg}$.

\section{Metabolically active roots}

The percentage of metabolically active roots at harvest of the sugar cane plant was not influenced by $\mathrm{N}$ fertilization at planting (Table 7). Both in the control (without $\mathrm{N}$ fertilization) as well as with the $\mathrm{N}$ rate of $120 \mathrm{~kg} \mathrm{ha}^{-1}$, the percentage of metabolically active roots was the same (38-40\%).

In relation to the distribution of metabolically active roots of sugar cane, at the sugar cane harvest most of the live roots were found in the surface layer near the stool (Table 8). In general, the distribution of the metabolically active roots appears not to have been influenced by $\mathrm{N}$ fertilization, and may be influenced by other factors.

Faroni (2004) evaluated metabolically active roots in sugar cane ratoon with the same method as used in this study and found different results than those presented here. The author found in the mean of four sampling periods (January, March, May and June) during the cycle of a second cutting, a greater percentage of distribution of live roots in the deep $(31 \%)$, than in the surface soil layers (23\%). In the study of Faroni (2004), soil moisture was greater in the deeper layers than in the surface layers in January, May and June, which may be associated with the greater percentage of live roots in the deeper

Table 7. Percentage of metabolically active roots of the total mass found at sugar cane harvest, in terms of nitrogen fertilization at planting

\begin{tabular}{lcc}
\hline \multirow{2}{*}{ Result } & \multicolumn{2}{c}{ N rate $\left(\mathbf{k g ~ h a} \mathbf{~ h}^{-1}\right)$} \\
\cline { 2 - 3 } & $\mathbf{0}$ & $\mathbf{1 2 0}$ \\
\hline Metabolically active roots (\%) & $40 \mathrm{a}$ & $38 \mathrm{a}$ \\
Standard deviation & 4.6 & 10.1 \\
Variation coefficient (\%) & 11.6 & 26.6 \\
\hline
\end{tabular}

$\overline{\text { Equal lower-case letters in the rows are not significantly }}$ different by the Tukey test at $5 \%$ probability. Standard deviation of average for $n=4$. 
Table 8. Percentage of metabolically active roots of the total mass found at each location at sugar cane harvest, in terms of nitrogen fertilization at planting, by depth and distance from the stool

\begin{tabular}{|c|c|c|c|c|c|c|}
\hline \multirow{2}{*}{ Depth } & \multicolumn{5}{|c|}{ Distance from the cane row (m) } & \multirow{2}{*}{ Average } \\
\hline & $0-0.3$ & $0.3-0.6$ & $0.6-0.9$ & $0.3-0.6$ & $0-0.3$ & \\
\hline \multirow[t]{2}{*}{$\mathrm{m}$} & & 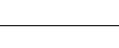 & 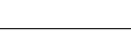 & 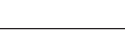 & 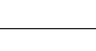 & - \\
\hline & \multicolumn{6}{|c|}{ Without fertilizer-N } \\
\hline $0-0.2$ & 54 & 11 & 11 & 39 & 46 & 47 \\
\hline $0.2-0.4$ & 41 & 8 & 13 & 22 & 37 & 39 \\
\hline $0.4-0.6$ & 23 & 15 & 8 & 9 & 21 & 20 \\
\hline \multirow[t]{2}{*}{ Average } & 49 & 13 & 11 & 38 & 40 & 40 \\
\hline & \multicolumn{6}{|c|}{$120 \mathrm{~kg} \mathrm{ha}^{-1}$ of urea-N } \\
\hline $0-0.2$ & 43 & 11 & 11 & 10 & 42 & 44 \\
\hline $0.2-0.4$ & 26 & 12 & 9 & 11 & 37 & 32 \\
\hline $0.4-0.6$ & 29 & 13 & 14 & 11 & 23 & 26 \\
\hline Average & 41 & 12 & 11 & 12 & 48 & 38 \\
\hline
\end{tabular}

layers. Aguiar (1978) observed a greater percentage of apparently live roots in the layer $0-0.2 \mathrm{~m}$ from October to May; in the layer $0.2-0.4 \mathrm{~m}$ from May to October and in the layer $0.4-0.6 \mathrm{~m}$ from May to December, associating the soil water availability to the variability found in the distribution of apparently live roots.

A small quantity of metabolically active roots was observed between the crop rows, regardless of $\mathrm{N}$ fertilization. Faroni \& Trivelin (2004) observed a trend of greater ${ }^{15} \mathrm{~N}$ labelling in the roots near the soil surface and near the sugar cane row, attributing this effect to a possible lack of uniformity in translocation of ${ }^{15} \mathrm{~N}$ in the root system. The authors also comment that the presence of plant roots of adjacent rows may favor the dilution of the tracer $\left({ }^{15} \mathrm{~N}\right)$ in roots between the rows since in that study only the plants in the center of the row received labelling with Urea ${ }^{15} \mathrm{~N}$. This was probably not the case in the this study because the roots were collected from the middle between two sugar cane rows that received urea- ${ }^{15} \mathrm{~N}$ solution for labelling of the root system, with the chance of the presence of plant roots of other than those labelled being very small.

\section{CONCLUSIONS}

1. For the evaluation of sugar cane root mass, probe sampling with $0.055 \mathrm{~m}$ diameter was similar to the monolith method.

2 . To evaluate sugar cane root and rhizome mass distribution, the use of methods that evaluate a larger soil volume is recommended.
3. There was no effect of nitrogen rates on the sugar cane root mass down to a depth of $0.6 \mathrm{~m}$.

4. Nitrogen fertilization at planting modified the distribution of sugar cane roots, favoring root growth near the $\mathrm{N}$-fertilized soil region, contributing to less deep roots in the soil profile compared to the plots without $\mathrm{N}$ fertilization.

$5.65 \%$ of the roots were concentrated in the surface layer to a depth of $0.2 \mathrm{~m}$ and $80 \%$ were distributed in the soil volume included in the $0.6 \mathrm{~m}$ surrounding the stool ( $0.3 \mathrm{~m}$ on either side), down to a depth of $0.6 \mathrm{~m}$.

6. At harvest of the sugar cane plant, the percentage of metabolically active roots was $40 \%$ of the total root mass, concentrated near the stool of the sugar cane.

\section{ACKNOWLEDGEMENTS}

To Fundação de Amparo a Pesquisa do Estado de São Paulo (FAPESP) for a scholarship of the first author (06/51251-0) and financing of Thematic Project (02/10534-8); Usina Santa Adélia (Santa Adélia Sugar Cane Mill) and Centro de Tecnologia Canavieira - CTC (Sugar Cane Technology Center) for logistic and personal support.

\section{LITERATURE CITED}

AGUIAR, S.F. Observações sobre sistema radicular de cana planta (Saccharum spp). Jaboticabal, Universidade Estadual Paulista, 1978. 24p. 
ATKINSON, D. Root characteristics: Why and what to measure. In: SMIT, A.L.; BENGOUGH, A.G.; ENGELS, C. van NORDWIJK, M.; PELLERIN, S. \& van de GEIJN, S.C., eds. Root methods: A handbook. Berlin, SpringerVerlag, 2000. p.305-341.

BALL-COELHO, B.; SAMPAIO, E.V.S.B.; TIESSEN, H. \& STEWART, J.W.B. Root dynamic in plant and ratoon crops of sugar cane. Plant Soil, 142:297-305, 1992.

BARRIE, A. \& PROSSER, S.J. Automated analysis of lightelement stable isotopes by isotope ratio mass spectrometry. In: BOUTTON, T.W. \& YAMSAHI, S., eds. Mass spectrometry of soils. New York, Marcel Dekker, 1996. p.1-46.

BÖHM, W. Methods of studying root systems. Berlin, SpringerVerlag, 1979. 188p.

CASAGRANDE, A.A. Tópicos de morfologia e fisiologia da cana-de-açúcar. Jaboticabal, FUNEP, 1991. 157p.

DREW, M.C. Comparison of the effects of a localized supply of phosphate, nitrate, ammonium and potassium on the growth of the seminal root system, and the shoot, in Barley. New Phytol., 75:479-490, 1975.

EMPRESA BRASILEIRA DE PESQUISA AGRPECUÁRIA EMBRAPA. Centro Nacional de Pesquisas de Solos. Sistema brasileiro de classificação de solos. 2.ed. Rio de Janeiro, Embrapa Solos, 2006. 306p.

FARONI, C.E.; TRIVELIN, P.C.O.; SILVA, P.H.; BOLOGNA I.R.; VITTI, A.C. \& FRANCO, H.C.J. Marcação de fitomassa de cana-de-açúcar com aplicação de solução de uréia marcada com ${ }^{15}$ N. Pesq. Agropec. Bras., 6:851-857, 2007.

FARONI, C.E. \& TRIVELIN, P.C.O. Quantificação de raízes metabolicamente ativas de cana-de-açúcar. Pesq. Agropec. Bras., 41, 6:1007-1013, 2006

FARONI, C.E. Sistema radicular da cana-de-açúcar e identificação de raízes metabolicamente ativas. Piracicaba, Escola Superior de Agricultura "Luiz de Queiroz", 2004 68p. (Tese de Mestrado)

FARONI, C.E. \& TRIVELIN, P.C.O. Avaliação do sistema radicular de cana-de-açúcar pela técnica da diluição isotópica com ${ }^{15} \mathrm{~N}$. In: FERTIBIO. 2004. Lages, SBCS; UDESC, 2004. CD-ROM

FURLANI, P.R. Toxidade de alumínio e toxidez em plantas. In: RAIJ, B.van; BATAGLIA, O.C. \& SILVA, N.M. Acidez e calagem no Brasil. Campinas, Sociedade Brasileira de Ciência do Solo, 1983. p.78-86.
GEE, G.W. \& OR, D. Particle-size analysis. In: DANE, J.H. \& TOPP, G.C. eds. Methods of soil analysis: Physical methods. Madison, American Society of Agronomy, 2002. p.255-289.

KÖPKE, V. Methods for studying root growth. In: SYMPOSIUM ON THE SOIL/ROOT SYSTEM, Londrina, 1980. Proceedings. Londrina, Fundação IAPAR, 1981. p.303-318.

LETEY, J. Relationship between soil physical properties and crop production. Adv. Soil Sci., 1:277-294, 1985.

RAIJ, B.van; ANDRADE, J.C.; CANTARELLA, H. \& QUAGGIO, J.A.. eds. Análise química para avaliação da fertilidade de solos tropicais. Campinas, Instituto Agronômico de Campinas, 2001. 285p.

SAMPAIO, E.V.S.B.; SALCEDO, I.H. \& CAVALCANTI, F.J.A Dinâmica de nutrientes em cana-de-açúcar. III: Conteúdo de nutrientes e distribuição radicular no solo. Pesq. Agropec. Bras., 22:425-431, 1987.

SOIL SURVEY STAFF. Keys to soil taxonomy. 9.ed. Washington, United States Department of Agriculture/ National Resources Conservation Service, 2003. 332p.

TROUSE JR., A.C. Effects of soil compression on the development of sugar cane roots. In: CONGRESS OF THE INTERNATIONAL SOCIETY OF SUGAR CANE TECHNOLOGISTS, 12., San Juan, 1965. Proceedings. Amsterdam, International Society of Sugarcane Technologists, 1967. p.137-152.

van NOORDWIJK, M. Roots: Length, biomass, production and mortality. In. ANDERSON, J.M. \& INGRAM, J.S.I., eds. Tropical soil biology and fertility: A handbook of methods. Wallingford, CAB International, 1993. p.132144.

VASCONCELOS, A.C.M.; CASAGRANDE, A.A.; PERECIN, D.; JORGE, L.A.C. \& LANDELL, M.G.A. Avaliação do sistema radicular de cana-de-açúcar por diferentes métodos. R. Bras. Ci. Solo, 27, 3:849-858, 2003.

VASCONCELOS, A.C.M. O sistema radicular da cana-deaçúcar e a expressão do potencial de produção. STAB, $21: 2-20,2002$

WAISEL, Y.; ESHEL, A. \& KAFKAFI, U., eds. Plant roots the hidden half. Madison, Marcel Dekker, 2002.1120p.

ZONTA, E.; BRASIL, F.C.; GOI, S.R. \& ROSA, M.M.T. O sistema radicular e suas interações com o ambiente edáfico. In: FERNANDES, M.S., ed. Nutrição mineral das plantas. Viçosa, MG, Sociedade Brasileira de Ciência do Solo, 2006. p.7-52. 
